\title{
Analysis of Influence of Intrinsic Aspect, Demography Aspect and Service of Zakat Institution toward Zakat Payment to Zakat Institution
}

\author{
Ahmad Mifdlol Muthohar \\ IAIN Salatiga, Indonesia \\ mifdlol@gmail.com
}

\begin{abstract}
This study aimed to determine the concept of the blessing of zakat and the muzaki'sperception about the blessings and to find internal factors that affected the muzaki in issuing zakat to zakat institutions. These factors were the service of zakat institutions, muzaki's religiosity, feeling blessed, gender, education level, and occupation, whether all of which affected the propensity of their choice in issuing zakat to zakat institutions. Sampling used purposive random sampling. For data analysis tools, this study used multiple regression analysis with tobit models. The findings in this study showed that the feeling of blessing by issuing zakat and occupational factors did not significantly influence the preferences of muzaki to issue zakat to certain zakat institutions. For the service of zakat institution, gender, and education level, they significantly and positively affected the preferences to issue zakat to zakat institutions. The variable of muzaki's religiosity negatively affected the trend in the choice of muzaki to issue zakat to zakat institutions significantly.
\end{abstract}

Keywords: Muzaki, Zakat Institutions, Blessing

\begin{abstract}
Abstrak
Penelitian ini bertujuan untuk menentukan konsep berkah zakat dan persepsi muzaki tentang berkah dan untuk menemukan faktor-faktor internal yang mempengarubi muzaki dalam menerbitkan zakat ke lembaga zakat. Faktor-faktor ini adalah layanan lembaga zakat, religiusitas muzaki, perasaan diberkati, jenis kelamin, tingkat pendidikan, dan pekerjaan, baik yang semuanya mempengarubi kecenderungan pilihan mereka dalam menerbitkan zakat kepada lembaga zakat. Pengambilan sampel menggunakan purposive random sampling. Untuk alat analisis data, penelitian ini menggunakan analisis regresi berganda dengan model tobit. Temuan dalam penelitian ini menunjukkan bahwa perasaan berkah dengan mengeluarkan zakat dan faktor pekerjaan tidak secara signifikan mempengarubi preferensi muzaki untuk mengeluarkan zakat ke lembaga zakat tertentu. Untuk layanan lembaga zakat, jender, dan tingkat pendidikan, mereka secara signifikan dan positif mempengarubi preferensi untuk mengeluarkan zakat ke lembaga zakat. Variabel religiusitas muzaki berpengarub negatif terbadap tren piliban muzaki untuk mengeluarkan zakat ke lembaga zakat secara signifikan.
\end{abstract}

Kata Kunci: Muzaki, Institsi Zakat, Keberkahan

Permalink/DOI: http://dx.doi.org/10.18326/infs13.v13i1.25-50 


\section{Background of Study}

The concept of zakat simply affirms that in the wealth of the rich there is right for the poor that should be given. This means that the obligation of zakat is more emphasized as the effort to equally distribute the income. The distribution of income is considered important by the Qur'an, so it appears in the Qur'an that property should not be circulated among the rich only (QS Al-Hashr: 7). Dealing with the distribution of income through zakat funds, there is an interesting article that explains the potential of zakat funds in Indonesia, which was held by PIRAC (Public Interest Research and Advocacy Center) in 10 big cities. The result shoewd that the potential of zakat funds in Indonesia reached Rp. 9.09 trillion in 2007 with the assumption that there were 29.065 million prosperous families who pay zakat on average Rp. 684,550 per year per person (Antara, 2008).

PIRAC also found that the level of awareness of muzaki on the obligation to pay zakat increased from $49.8 \%$ in 2004 to $55 \%$ in 2007. As a result, most of the muzaki then paid it, that is $95.5 \%$ of them. Thus, from $55 \%$ of people who are aware of their zakat obligations, 95.5\% then pay the zakat (Antara, 2008). Research conducted by PIRAC showed that $45 \%$ of Muslims in Indonesia are obliged to pay zakat, but they are still not paying it. The number of $45 \%$ is quite large. If the assumption of zakat fund potential in Indonesia is Rp. 9.09 trillion, then 4.30 trillion among them are still not aware of the obligations of zakat.

Hidayat Nurwahid said that zakat potential of the people of Indonesia reached $\mathrm{Rp} 17$ trillion. It is almost twice more compared with the finding of PIRAC. Nevertheless, the realization is less than 2.5 percent or only Rp 700 billion. It means that there is still 16.5 trillion that has not been collected (Antara, 2008). Another study, Asian Development Bank (ADB) states, that the potential of collecting zakat in Indonesia can reach up to Rp 100 trillion per year (Rama, 2010). And even the last result mentioned that the potential of zakat that can be collected in the country reached $\mathrm{Rp} 217$ trillion per year, based on a survey conducted by BAZNAS, Bogor Agricultural Institute (IPB) and Islamic Development Bank (IDB) in 2011 (Republika, 2013). 
One of the problems is lack of awareness to pay the zakat. More specifically, they lack of awareness to pay zakat funds to zakat institutions. Some previous studies have mentioned that there are many factors that affect muzaki to pay zakat in zakat institutions, one of those is the factor of income, religiousity, work ethic variables and the role of pesantren (Syafei, 2003). There is also a person who said that the factors that cause people not paying zakat to the Badan Amil Zakat (BAZ) are: (1) Psychological factors (they are worried their zakat will not be well distributed; (2) Sociological Factors (the tradition of paying zakat directly to mustahik); (3) Transparency Factors in BAZ; (4) Non-optimal promotional factors; (5) Human Resources Factors that specifically manage zakat funds (Rosadi, 2007). Some others say that blessing is one of the factors that motivate timber entrepreneurs to pay their zakat (Hervina, 2004).

The blessing factor is the factor that becomes the important foundation in this research. Some Islamic economists have discussed the blessing factor in economic activity, but they have not elaborated the meaning of blessing itself. For example Zamir Iqbal and Abbas Mirakhor, one of the Islamic economists who reminded the importance of motivational factors in the Islamic system, namely blessing factor (Iqbal and Mirakhor, 2007: 42-43).

Among the factors mentioned above, many researchers emphasize the discussion on either external or internal factors. In this study, the researcher focused on internal factors of muzaki that cause them pay zakat to zakat institutions. These factors are the feeling of the blessing of muzaki and the personal religiosity of muzaki, as already exists in some of the above studies.

While other additional factors are the factors of gender, job factor and educational factor. In terms of gender, many studies mention the different way of brain work beween men and women. There are 6 (six) differences which cause a man to think more rationally. Whereas in women, intuitive thought that tend to be governed by the right brain, it is more easily related to the rational mind set by the left brain. So no wonder if women's rationality is overlap with intuition (Pasiak, 2007: 123-124). The existence 
of these differences, can lead to differences in the perception in paying zakat to zakat institutions or directly to mustabik.

The next factor affecting the payment of zakat to zakat institution is the work factor. Some studies found that a job in the government sector is very attractive to employees looking for job security, as Kilpatrick, Cummings and Jennings did, in 1964 (p. 2324); Bellante and Link, in 1981 (p. 408-412) and Baldwin, in 1991 (p. 1-27). Although there are several studies that draw different conclusions, the majority say that the work in government sector is more interesting, mainly because of the element of job security. Therefore, the job factor, ie if a person works as a Civil Servant (PNS) or others, it may ecourage the muzaki to pay zakat to zakat institution.

Another internal factor that may affect muzaki to pay zakat to zakat institution is the educational factor. According to Noeng Muhadjir, many cases are found that the increase of one's intellectual abilities is in line with education level or tasks, functions and challenges (Muhadjir, 2000: 50-51). Hence, when muzaki is more capable of thinking, it can cause him to pay zakat to zakat institution.

In order to produce an unbiased research result, it is necessary to have an external factor which is the control variable of the internal factors, ie the service factor done by the zakat institution, as mentioned above.

Some of the factors above lead researchers to explore more deeply related to internal factors that affect muzaki to pay zakat to zakat institutions. Furthermore, there is one important point of the factor that becomes the focuse in this research, namely the feeling factor of blessing. Therefore, this study entitled, "The Preference of Blessing Feeling in the Tendency of Zakat Options to Zakat Institution on Joglosemar Line". 


\section{Problem Statements}

The formulation of problems that can be taken from the above problems as follows; a). Does the blessing feeling have a significant and positive effect on the tendency of muzaki's choice to pay zakat to zakat institution; b) Does religiosity of muzaki significantly and positively effect on tendency of choice of muzaki to pay zakat to zakat institution; c) Does gender positively and significantly influence on the tendency of choice of muzaki to pay zakat to zakat institution; d) Does the level of education significantly and positively effect on the tendency of choice of muzaki to pay zakat to zakat institution. e) Does the work factor significantly and positively effect on the tendency of choice of muzaki to pay zakat to zakat institution; f) Does zakat institution service have a significant and positive effect on the tendency of muzaki's choice to pay zakat to zakat institution.

\section{Literature Review}

The theory used in this research is Gomes' work motivation theory ([2003]: 180), which is combined with Clifford Geertz's theory of religious motivation (1973: 90). In addition, phenomenology theory is also used to explain the meaning of blessing in life of Indonesian Muslim society. The phenomenology theory used is Edmund Husserl's theory. According to Husserl, the first thing to do is to eliminate all the beliefs from our actions we have now, including all of our knowledge. Let the idea guide all of our meditations at first into an idea of a science that will radically be confirmed and pure which finally encompasses all the content of knowledge (Husserl, 1966: 49).

In Q.S. al-A'raf [6]: 96 it has been explained that if the people of the lands believe and fear of Allah, surely Allah will bestow upon them the blessings from sky and earth, but they deny (the verses), so Allah tortures them for lying.

Every Muslim must believe that when they really believe and fear of Allah, they will surely get blessings from God s.w.t. which comes from both sky and earth. Faith and piety are certainly in 
accordance with standards set by God s.w.t and His Messenger, through the Qur'an and Sunnah of the Prophet s.a.w. It is stated by al-Baidhawi $(791 \mathrm{H})$ that issuing zakat will attract the blessing of the treasure and bring about the virtue of the soul (Al-Baidhawi, [1998], Vol. I: 291). Similarly, an-Naisaburi argues that the definition of zakat according to Islamic law is the level of property taken out from the treasure that has reached one nisab, where it will add blessing to the treasure (An-Naisaburi, [1994], Vol. I: 209).

Zamir Iqbal says that one important aspect in analyzing an economic system is related to the structure of motivation that will be pushed by the system itslef. The purpose of this aspect of motivation is to make sure whether an individual in the system will make that motivation as utility-maximizing when following the rules elaborated by the system, or vice versa. The important motivation factor in Islamic system is the existence of blessing concept. This concept refers to the existence of an invisible blessing, but it is the form material blessing whose results can be observed. It starts from a motivated behavior and a goal to achieve the pleasure of Allah s.w.t., which can increase the rate of profit.

The Behavior is primarily because it presents blessing. This blessing concept affirms that spending treasure for the sake of God without expecting profit from the recipient does not actually diminish wealth, instead of developing it (Iqbal and Mirakhor, 2007: 42-43).

The concept of blessing as mentioned by Iqbal above prevails to all Islamic rules that must be obeyed by every Muslim. Indonesian people are more familiar with the term blessing. Some of the rules to be followed to gain blessings from Allah s.w.t. is associated with the obligation of zakat. The implementation of zakat must be supervised by the zakat officer, carried out by a neat officer and collected from the people who have obligation to pay it, and is given to those who have right to receive it. That is because zakat itself is the obligation of every Muslim individually, to ensure the groups of Muslim whose needs have not been fulfilled economically (Abdurrasul, 1980: 175). The proposition of zakat that it should be administered directly by the government is Q.S. At-Taubah [9]: 103 as follows: 
Take zakat from some of their property, with that zakat you clean and purify them and pray for them. Verily, your prayer is a serenity for them. and Allah is All-Aware of Knowing (Q.S. AtTaubah [9]: 103).

In the verse it is clear that Allah's command is directly addressed to the Prophet s.a.w. as the ruler to collect the wealth of charity. The majority of ulama since the past time until now said that the meaning of charity in the verse is the wealth of zakat. (AlQaradhawi, 1973: 734). The command is addressed not only to the Prophet s.a.w., but also to everyone who takes care of the affairs of the Muslims afterwards.

Khalifah Abu Bakr also used this verse as proposition, when he was about to fight against those who would not pay zakat after the death of Prophet s.a.w. None of his friend who said that the verse is not for the obligation of zakat. Likewise, Islamic scholars after them, in order to reject all this dubiousness.

In hadith narrated by Bukhari, Muslim, Abu Dawud, Tirmidhi, an-Nasa'i and Ibn Majah, from Ibn Abbas that the Prophet s.a.w. when he sent Muadz to Yemen, he said:

Tell them that Allah s.w.t. has required some of their wealth, to be given away. Taken from the rich to be given to the needy. If they obey you in this matter, keep the honor of their wealth and fear the prayers of the persecuted. There is absolutely no barrier between their prayers and Allah s.w.t. (HR.6 The leading narrator, from Ibn Abbas).

This hadith explains that the affair of zakat is administered by officers to be distributed, not done by the person who issued the zakat. Al-'Asqalani explains that the ruler is the person who is in charge of collecting and distributing zakat, either he himself directly or by his appointed deputy. If they refuse, the zakat will be forcibly taken from them (Al-Asqalani, Vol. III: 23).

Contemporary scholars such as Abdul Wahab Khalaf and Muhammad Abu Zahrah, as described by al-Qaradawi, say that if the ruler knows that his people do not pay zakat, then they should take it by force (Al-Qaradhawi, Vol. 2: 1973: 734). 
Furthermore, the theoretical framework in this study can be explained through the following scheme:

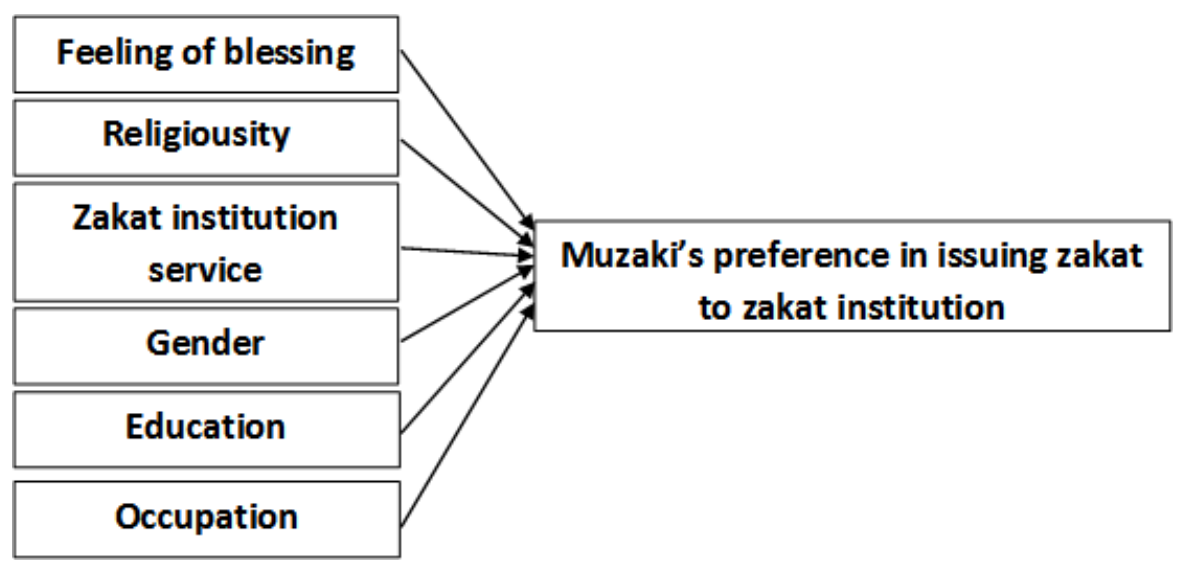

Figure 1. Research Scheme

From the scheme, it can be seen that the hypothesis in this study are as follows:

1. Factor of blessing has a significant and positive effect on zakat payment tendency to zakat institution in Joglosemar area.

2. Factor of religiosity of muzaki a significant and posituve effect on zakat payment tendency to zakat institution in Joglosemar area.

3. Zakat institution service factor has a significant and positive effect on zakat payment tendency to zakat institution in Joglosemar area.

4. Gender factor has a significant and positive effect on zakat tendency to zakat payment institution in Joglosemar area.

5. Educational level factor has a significant and positive effect on zakat paymeny tendency to zakat institution in Joglosemararea.

6. Factor of muzaki's work has a significant and positive effect on zakay payment tendency to zakat institution in Joglosemar area. 


\section{Research Methods}

The scope of this research is Joglosemararea. As ruled in Regulation of Central Java No. 212003 stating that Joglosemar area is a region of inter-provincial cooperation that has certain specificity. It has the following criteria: (1) Areas that have contribution to the achievement of target nationally; (2) Areas which are not included in the delineation of certain areas and mainstays but from the provincial dimension they have a role for growth and even great distribution; (3) Areas with spatial problems that must be solved immediately. Joglosemar area includes Jogjakarta, Solo and Semarang and the lane passing Joglosemar is an important and strategic lane. The lane is passed by 13 regencies/cities, namely: Yogyakarta, Klaten, Surakarta (Solo), Sukoharjo, Karanganyar, Boyolali, Salatiga, Semarang regency, Semarang City, Temanggung, Magelang Regency, Magelang City and Sleman. The reason for choosing Joglosemar lane as the object of research is because this lane is the largest business lane in Central Java and Yogyakarta, the community is heterogeneous.

The research design used in this study is exploratory research design. In this design, the researcher conducted the study by collecting qualitative data first and then followed by quantitative research. Qualitative research produces formulation of proposition and then it is investigated by quantitative research. The procedures are as follows: (1) Collecting qualitative data; (2) Analyzing qualitative data; (3) Proving data qualitatively; (4) Developing instrument; (5) Collecting quantitative data; (6) Analyzing quantitative data; (7) Proving data quantitatively; (8) Qualitative and quantitative analysis (Syam, 2011).

Qualitative data collection conducted by researcher was related to the variables of blessing feeling, religiosity and service of zakat institutions. After it finished then quantitative data was collected. And last is the inference of qualitative and quantitative data.

Dependent variable in this research is the tendency of zakat payment to zakat institution. While the independent variables are zakat institution service, muzaki's religiosity, blessing feeling, 
education level, occupation and gender. The research scheme has been explained in figure 3 above.

The population of muzaki in this study was not known, so there is no representative method for taking the samples. That's because the data about the total number of muzaki is not found. Therefore, the method used to determine the number of samples under unknown population condition is to consider the population as an infinite number. According to Sugiyono, if the population is infinite, the number of samples of $95 \%$ for confidence level or margin of error 5\% is 349 respondents (Sugiyono, 2009: 70-71).

Sampling technique used in this study is purposive random sampling, that is sampling technique in which in this case the researcher determined the boundaries of the subjects used as research samples, namely: 1) Respondents who pay zakat to government-owned zakat institutions (BAZ), and non-government (LAZ); 2) Respondents who pay zakat to BAZ / LAZ and also directly to mustabik; 3) Respondents who pay zakat directly to mustabik; 4) Respondents who pay zakat to amil zakat in mosque or mushalla; 5) Respondents who pay zakat to zakat institutions not mentioned above.

The data in this research consists of two types, primary data and secondary data; 1) Primary data is based on field research; 2) Secondary data is based on library research. Secondary data is used to reveal the opinions of experts, scholars, either classical or contemporary and other resources needed in this study. Methods of collecting data used in this research are: research questionnaires, interviews, observation and doumentation.

Qualitative analysis in this research is done through three stages: (1) Editing stage, is used as preparation to check collected data as well as to check its validity, (2) Tabulation stage, is used to classify relevant and irrelevant data, the researcher obly took the data which is relevant with the research, (3) Analysis stage, that is comparing, drawing conclusions and creating new categories based on research objectives.

While the quantitative analysis used in this research is multiple linear regression analysis. This analysis aims at measuring 
the blessings when people pay their zakat to zakat institution, mushalla / mosque or directly given to the recipient of zakat by assuming that there are 6 factors causing muzaki to pay their zakat to zakat institution, that is due to the exixtance of zakat institution service (L), due to the religiosity of muzaki (R), due to the feeling of blessing of zakat (B), gender (J), education (Pd) and work (Pk). The mathematical equation is as follows:

Where:

$$
\begin{array}{ll}
\mathrm{P} & =f(\mathrm{~L}, \mathrm{R}, \mathrm{B}, \mathrm{J}, \mathrm{Pd}, \mathrm{Pk}) \\
\mathrm{P} & =\beta 0+\beta 1 \mathrm{~L}+\beta 2 \mathrm{R}+\beta 3 \mathrm{~B}+\beta 4 \mathrm{~J}+\beta 5 \mathrm{Pd}+\beta 6 \mathrm{Pk}+\varepsilon
\end{array}
$$

P (Y) = Tendency of zakat payment to zakat institution

$\mathrm{B}(\mathrm{X} 3)=$ Muzaki's blessing feeling

$\mathrm{R}(\mathrm{X} 2)=$ Religiosity of $M u z a k i$

$\mathrm{L}(\mathrm{X} 1)=$ Zakat institution service

$\mathrm{J}(\mathrm{X} 4)=$ Gender

Pd $(X 5)=$ Level of education

$\mathrm{Pk}(\mathrm{X6})=\mathrm{Job}$

The method used to analyze the data is regression analysis of Tobit model, not Ordinary Least Square (OLS) model. Tobit model analysis was chosen because in this study there are zero answers of the questions given to respondents. Tobit analysis is a model assuming that the independent variable has a value limit, which is generally zero (Greene, 2002: 773-774). The Tobit method uses Maximum Likelihood (ML), not Ordinary Least Square. The use of Maximum Likelihood estimation in analyzing data requires a complete specification of the random variable distributions being researhed. Thus, there is no autocorrelation disease, no heteroscedasticity and no multicolinearity. On the contrary, maximum likelihood model makes the mathematical model used precise. Therefore, no autocorrelation test, heteroscedasticity test and multicolinearity test are required. 


\section{Research Findings}

The Influence of Independent Variables toward the Thendency of Zakat Payment to Zakat Institution

From the result of partial regression test, the influence of 6 independent variables to the dependent variable above can be described as follows:

Table 3. Summary of Partial Hypothesis Test Results

\begin{tabular}{|l|l|l|l|}
\hline No & \multicolumn{1}{|c|}{$\begin{array}{c}\text { Independent } \\
\text { Variables }\end{array}$} & \multicolumn{1}{|c|}{ Hipothesis } & \multicolumn{1}{|c|}{$\begin{array}{c}\text { Result of } \\
\text { Analysis }\end{array}$} \\
\hline X1 & Blessing & $\begin{array}{l}\text { Has significant } \\
\text { influence }\end{array}$ & Insignificant \\
\hline X2 & Religiosity & $\begin{array}{l}\text { Has significant } \\
\text { influence }\end{array}$ & $\begin{array}{l}\text { Has significant } \\
\text { influence }\end{array}$ \\
\hline X3 & $\begin{array}{l}\text { Zakat Institution } \\
\text { service }\end{array}$ & $\begin{array}{l}\text { Has significant } \\
\text { influence }\end{array}$ & $\begin{array}{l}\text { Has significant } \\
\text { influence }\end{array}$ \\
\hline X4 & Gender & $\begin{array}{l}\text { Has significant } \\
\text { influence }\end{array}$ & $\begin{array}{l}\text { Has significant } \\
\text { influence }\end{array}$ \\
\hline X5 & Education & $\begin{array}{l}\text { Has significant } \\
\text { influence }\end{array}$ & $\begin{array}{l}\text { Has significant } \\
\text { influence }\end{array}$ \\
\hline X6 & Occupation & $\begin{array}{l}\text { Has significant } \\
\text { influence }\end{array}$ & Insignificant \\
\hline
\end{tabular}

From the result of hypothesis test above, it was found that 6 predicted factors influenced the tendency of zakat payment to zakat institution, there were only 4 which influenced significantly. The 6 predicted factors are feeling of blessing, religiosity, service of zakat institution, gender, education and work. The 4 variables that have significant influence are the services of zakat institutions, religiosity, gender and education. From the 4 factors that have significant influence, 3 of them have a positive effect, namely the service of zakat institutions, gender and education. While one of them has a negative effect, namely religiosity. The other two variables (feelings of blessing and occupation) have no significant effect on the tendency of muzaki's choice to pay zakat to zakat institution. The followings are the explanation of the variables that have significant effect and those that don't: 
Variable of Blessing Feeling

Variable of blessing felt by muzaki has no significant effect on the tendency of their choice in issuing zakat to zakat institution. This means that muzaki do not assume that the feeling of blessing they feel is related to their tendency to zakat institution. If seen from the value of regression coefficient of the blessing variable, -1.461295 , it is known that the value is even negative. This means that if a muzaki feels a blessing in his zakat, then he tends to choose not to pay his zakat to the zakat institution.

When the respondents of muzaki were asked about whether they felt the blessing in performing the charity, from 396 respondents, 395 people felt the blessing and only 1 person stated that he did not feel the blessing. However, the feeling of blessing is not related to the issue of zakat payment to zakat institution. It means that both muzaki who pay their zakat directly to mustahik, and those who pay their zakat to zakat institution, they all feel blessed.

From the explanation above, it can be understood that the muzaki increasingly feel the blessing of zakat, it does not necessarily tend to give zakat to zakat institution or to mustahik.

From the deep analysis through the primary data found, there are several factors that cause it, based on information from the managers of zakat institutions in Joglosemar lane. There are about 20 zakat institution managers interviewed by the researcher. They mentioned that at least there are three things that cause the condition, namely zakat institution factor, muzaki factor and government factor.

Based on the result of interview to some zakat institution managers in Joglosemar lane, six of them mentioned that the cause is from zakat institution and muzaki, so the total is 26 answers. From 26 responses, 14 (54\%) of them said that the main factor is from the bad management of zakat institutions (Hidayat, etc., 17-20/2/2014). While 11 answers (42\%) mentioned that the main factor is started from muzaki themselves (Hidayat, etc., 1720/2/2014). And one answer (4\%) mentioned that the main and 
key factor is not coming from zakat institutions or muzaki, but it is coming from government (Taufikurrahman, 18/2/2014). So, the first dominant factor that causes muzaki increasingly pay zakat to zakat institutions is due to the factors coming from the zakat institution itself.

\section{Variable of Religiusity}

The statements related to the regression result of bless feeling variable are different from the regression result of the religiosity variable. The variable of religiosity of muzaki significantly influenced the tendency of their choice to pay zakat to zakat institution. But it has a negative influence. This means that when muzaki are more religious, they will choose more to pay zakat to zakat institutions. This is contrary to the previous assumption, that the more religious the muzaki, the more they attempt to pay their zakat to zakat institution.

The results of regression above reinforce the research findings of Syaparuddin (2010) and Bawono (2010), there are some differences in both findings. Syaparuddin's findings conclude that muzaki's religiosity has no significant effect on the amount of zakat payment to zakat institutions.

The meaning of this research findings indicates that religious muzaki in Joglosemar region are not interested in paying zakat to zakat institution or mosque. It is normal that according to Hidayat Nurwahid zakat funds of the society of Indonesia reached up to Rp 17 trillion (Antara, 2008). According to PIRAC, zakat funds in 10 big cities in Indonesia reached Rp. 9.09 trillion (2007), and it can not be utilized optimally. According to Nurwahid the realization of collected zakat funds did reach not up to 2.5 percent, only $\mathrm{Rp} 700$ billion. It means that there is still 16.5 trillion that has not been collected.

Such tendency indicates that more religious muzaki will not pay their zakat to zakat institution. According to Daud Ali Muslim's understanding of zakat institutions is very limited when compared with their understanding of prayer and fasting. This is 
because Islamic religious education in the past did not explain the meaning and the problem of zakat. As a result, due to lack of understanding, the implementation of zakat decreased (Ali, 1988: 54). It seems that this limitation of understanding is still valid until now, and it is proven that muzaki who know that the era of Prophet s.a.w. they know that zakat given to government-baitul mas- is only 130 people (33\%) of the total muzaki of 396 people.

This case is exacerbated by the politics of East Indies government in the past that forbade government officials to intervene in the management of zakat, for it is worried to be fundraiser for Muslims, as stated in Bijbad No. 1892 on August 4, 1893 about the supervision of the implementation of zakat and fitrah. This later became tradition in Indonesian government, even we still feel the effect until now.

These religious variables include 5 dimensions: faith, worship, morals, knowledge and good deed. From the data above, the highest value of religiosity dimension is good deed $(8,57)$, then followed by worship $(8,36)$, faith and morality have the same value $(8,14)$ and the last is knowledge dimension $(7,23)$. This shows that the religiosity of the Joglosemar community has a fairly weak base of knowledge compared to other religious dimensions. Nevertheless, the religious devotion of muzaki is high, although they have limited knowledge.

The religious muzaki's tendency to choose paying zakat directly to mustahik is not something that comes suddenly. From the questionnaire about religiosity which includes 5 dimensions (ideological, ritualistic, experiential, consequential and intellectual). It is found that the lowest value is intellectual dimension, or in Nashori, knowledge dimension. So it can be concluded that the religious muzaki, if they choose to pay zakat directly to mustahik, it is because they have limitated of knowledge about the importance of zakat institutions. This finding is based on the questionnaire results which confirmed that among 396 respondents, only 130 respondents (33\%) who know that zakat in the era of Prophet s.a.w. was given to government or zakat institution. 


\section{Variable of Service of Zakat Institution}

Variable of service of zakat institution has significant influence to tendency of muzaki to pay their zakat to zakat institution in Joglosemar area. This means that in general, in Joglosemar area, muzaki assume that the service of zakat institutions becomes their driving factor in giving their zakat to zakat institution. The value of regression coefficient of zakat service institution is quite high, that is $\mathbf{9 . 8 4}$. The service of zakat institution here includes several dimensions that become benchmarks, namely accountability, transparency, professionalism, accessibility, location, communication and popularity. But the dimensions are united into one variable, namely variable of service of zakat institution.

Based on research data of 396 respondents, it's only 74 muzaki (19\%) who paid zakat to zakat institution. While those who paid zakat to zakat institution and directly to mustabik there were 213 respondents (54\%). And the ones who paid their zakat only to mustabik were 109 respondents (27\%). So, the total number of muzaki who paid their zakat to zakat institution was 287 people. Of the 287 people (72\%), it was found that muzaki preferred to pay zakat to private-owned zakat institutions to the government-owned zakat institution, in this case thee were 165 muzaki (57\%). It is with the assumption that muzaki who paid zakat to the mosque is categorized in a separated group. If the mosque is considered as a private zakat institution, then there are 187 muzaki (65\%) who paid zakat to private zakat institution from the total respondents of 287 . While those who paid zakat to the government zakat institutions were only 39 people (14\%). And 61 respondents (21\%) did not answer.

From this data, it is known that the variable of service of zakat institution significanty influences the tendency of muzaki to pay zakat to zakat institution; actually it is dominated by private zakat institution. Therefore, it is not tume for the government to unite the management of zakat into one and managed by the government. Public opinion still can not be separated from the trust of private zakat institutions, compared to the government 
zakat institutions. The data is categorized if respondents are given choice to answer one type of zakat institution.

\section{Gender}

The gender variable is a dummy variable type. Male muzaki were predicted to think more rationally. Thus, male muzaki were predicted that they would pay their zakat to zakat institution. While female muzaki were predicted to highlight the feelings, so they will feel more compassionate towards the mustahik around them as the object of zakat funds target.

The result of regression coefficient value of this gender variable is 10,06531 . While the significant value is 0.0037 , smaller than 0.05 , male gender significantly affects the choice of muzaki to pay zakat to zakat institution in Joglosemar area. Scientific research does not really distinguish between the level of intelligence of men and women. But the difference is in how to use that intelligence, which makes men think more rationally than women, although their level of intelligence is not much different.

Apparently, the results of research on the behavior of muzaki in paying their zakat to zakat institutions also justify it. The majority of men are more rational in determining the choice of objects of zakat target. They are more likely to choose zakat funds managed by zakat institutions that will generally have a wide impact of its function. Even some zakat institutions make zakat funds that they manage for productive interest that relatively has longer function.

The reason of men for choosing zakat payment to zakat institutions is all based on rational reasons; no one has an emotional motive. The reasons are: practical, fair, equitable, transparent, accountable, on target, amil know about priority mustahik, easy, well organized, variation of mustahik, many programs, trusted, , Islamic doctrine and for productive interest (Puyawahana etc., 9 and 12/8/2012).

Then the reasons of women when they pay their zakat directly to mustabik are: first, rasional reason: right on target, fast 
and practical; second, emotional reasons: satisfied, close fellow, brotherhood, family needs more, more careful, and know more about the condition of mustahik (Widayati, etc., 10-12/2012).

\section{Education}

Educational variable significantly influences the tendency of muzaki in paying zakat to zakat institution. The regression coefficient value is 3.579700 . This means that the higher level of education of muzaki, the higher tendency of muzaki to pay zakat to zakat institutions. This is in line with the opinions of Lawrence Kohlberg and William Perry, who assert that the factor of change of intellectual and ethical development is cognition. The improvement of knowledge will change the dimension of perception and evaluation of one's attitude. When a person's level of education is low, he tends to have a narrow perception of a problem. Likewise, his attitude tends to be limited to the perception he has. This also considers the condition of muzaki that become the object of research. Lower level of education of muzaki will tend to have a narrow perception of the mustabik who become the object of zakat distribution. They did not think about the use of zalat funds that are more productive. Conversely, higher level of education muzaki will increasingly have the perception and attitude of dimension. Each zakat fund that they spend is always based on optimization of use for the wider community.

These findings are a development of previous findings which concluded that the higher the level of one's education, the higher the awareness to pay zakat (Sabili, 2012). The findings of this research showed that high level of education of muzaki is not just making their level of awareness of paying zakat. And they tend to have higher tendency to pay zakat to zakat institution.

Muhibbin Shah summarizes the opinion of a group of educational experts, that a person who has undergone a process of education or learning will experience the manifestation or manifestation of learning behavior, which often appears in certain changes, among which are rational and critical thinking in solving 
problems (Syah, 1999: 108-113). This means that the higher level of education of someone, it will increasingly have a more rational thinking pattern. This is also applied to muzaki after research. In fact, muzaki who have higher level of education have a rational thinking pattern, by delivering zakat to zakat institutions.

The difference between muzaki who have higher level of education and those who have lower level of education has been prescribed in Q.S. Az-Zumar [39]: 9 as follows:

Say (Muhammad), "Are those who know equal with those who do not know?" But only men of understanding will pay heed (Q.S. Az-Zumar [39]: 9).

The verse explicitly describes the difference between a knowing person and an unknowing person. Through the study, the difference is concluded by educational experts, that it is related to rational and critical thinking in solving problems, it is not aside from this case of zakat, when they are asked to choose to pay zakat to zakat institutions or directly to mustahik, they prefer to pay it to institution of zakat.

\section{Occupation}

Variable of occupation is dummy variable type, between Civil Servant and non-Civil Servant. The civil servant career is predicted to influence the tendency of muzaki's choice in issuing zakat to zakat institution. On the contrary, non-civil servant career is predicted not to affect the tendency of muzaki's choice in issuing zakat to zakat institutions. Thus, in this study, Civil Servant $=1$ and non-Civil Servant $=0$. From the existing data. The result showed that occupation variable of civil servants does not influence the tendency of muzaki's choice in issuing zakat to zakat

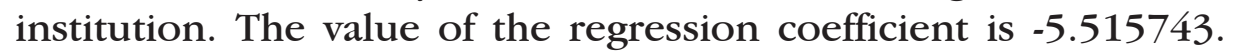
While the significant value is 0.1407 , greater than 0.05 . It means that the variable of occupation of civil servant does not significantly influence the tendency of muzaki's choice in issuing zakat to zakat institution. On the contrary, the variable of civil servants is not interest in pying zakat to zakat institutions. This means that a 
civil servant will be more likely to reduce paying zakat to zakat institution, just because the correlation is not significant.

The previous hypothesis states that civil servants are considered to be established and secure jobs, so muzaki will be able to think wisely in paying zakat, by paying zakat to zakat institutions. But it is not proven, and even the value of regression coefficient is negative it menas that civil servants actually more likely to reduce the payment of their zakat to zakat institutions, although the tendency is not significant.

\section{Conclusion}

Based on the data analysis elaborated above, research findings can be concluded as follows: 1) Blessing in issuing zakat for Muslims is to gain abundant virtue, which is unlimited, in the form of physical thing; such as the increase in property, all need is fulfilled, avoidance of disease. There are also non-physical things, such as calmness, tranquility, peace, happiness, inner satisfaction and the feeling that Allah respects and accepts their charity; and some are general (physical or non-physical), such as enjoying wealth and obtaining convenience from Allah; 2) $98 \%$ of muzaki stated that they feel the blessing in issuing zakat, and the highest blessing according to muzaki is feeling of calm, serenity and peace. However, when the high percentage is associated with the tendency to give zakat to zakat institution, there is no correlation among them. If any correlation, it tends to be negative, even though the correlation is not significant. The conclusion means that muzaki feel like they get more blessing when they give zakat to zakat institution, then they tend to pay their zakat to the zakat institution; 3) of six variables, four of them have significant effect on tendency of paying zakat to the zakat institution. And the other 2 have no significant effect. The variables that have a significant effect are as follows: a) Variable of religiosity has significant and negative effect on tendency of paying zakat to zakat institutions; b) Service variable has a significant and positive effect on the tendency of paying zakat to zakat institutions; c) Sex variable (male) has a significant and positive effect on the tendency of paying zakat to the zakat institution; d) Educational 
level variable has significant and positive effect on the tendency of paying zakat to the zakat institution.

The variables that have no significant effect are as follows: a) Variable of blessing level does not significantly influence the tendency of paying zakat to the zakat institution; however, there is still a negative correlation between the two, although it's not significant; b) Job variable (Civil Servant) do not significantly influence the tendency of paying to zakat institution, however, there is still a positive correlation between the two, although it's not significant. 


\section{Bibliography}

Abdurrasul, Ali. Al-Mabadi' al-Iqtishadiyyah fi al-Islam wa al-bina' al-iqtishadi li ad-Daulah al-Islamiyyah (Kairo: Daru al-Fikr al'Arabi, 1980), p. 175.

Al-Asqalani, Ibnu Hajar. Fathu al-Bary Syarh Shahih al-Bukhari (Beirut: Dar al-Fikr, tt), III, p. 23.

Al-Baghdadi, Abu al-Fadhl Syihabu ad-Din Mahmud al-Alusi. Tt. Ruhu al-Ma'ani fi Tafsiri al-Qur'ani al-'azhimi wa as-Sab'i alMasani, Beirut: Ihya-u at-Turats al-'Arabi, IX, p. 10-11.

Al-Baidhawi, Nashiru ad-Din Abu al-Khair Abdullah, bin 'Umar bin Muhammad. 1998. Anwar at-Tanzil Wa Asrar at-Ta'wil, Istanbul: Maktabah al-Haqiqah, I, p. 291.

Al-Jauziyyah, Ibnu Qayyim. 1998. Zadu al-Ma'ad fi Hadyi Khairi al'Ibad (Kairo: Daru al-Qalam li at-Turats, I, p. 262.

Al-Qaradhawi, Yusuf. 1973. Fiqhu az-Zakah, Beirut: Mu'assasat arRisalah, terj. Salman Harun dkk, dengan judul Hukum Zakat, cet. ke-6, terbitan PT. Pustaka Litera AntarNusa, Jakarta, p. 734. An-Naisaburi, Abu al-Hasan Ali bin Ahmad al-Wahidi. 1994 [w. 468 H]. cet. ke-1, Al-Wasith fi Tafsir al-Qur'ani alMajid, Beirut: Daru al-Kutub al-'Ilmiyyah, I, p. 209.

Andri. 2011. "Mengapa Kita Butuh Psikiater" in http:// kesehatan.kompasiana.com/medis/2011/06/27/mengapakita-butuh-psikiater/, tanggal 27 Juni, diakses tanggal 2 Agustus 2012.An-Naisaburi, Abu al-Hasan 'Ali bin Ahmad al-Wahidi. 1994 [w. 468 H], cet. ke-1, Al-Wasith fi Tafsir alQur'ani al-Majid, Beirut: Daru al-Kutub al-'Ilmiyyah, I, p. 209.

At-Thabrani, Hafizh Abi al-Qasim Sulaiman bin Ahmad. 1995. AlMu'jam al-Ausath, Kairo: Daru al-Haramain, no. hadis 6788, VII, p. 40. Ali, Mohammad Daud. 1988. Sistem Ekonomi Islam Zakat dan Wakaf, Jakarta: Penerbit UI, cet. ke-1, p. 54.

Baldwin, J. Norman. 1991. "Public versus Private Employees: Debunking Stereotypes" in Review of Public Personnel Administration, 1991, 11 (1/2), pp. 1-27. 
Baznas dan Fakultas Ekonomi dan Manajemen IPB. 2011. "Estimasi Potensi Zakat Nasional", in http://sabili.co.id/lentera/ estimasi-potensi-zakat-nasional, tanggal 22/8, diakses tanggal 8 Agustus 2012.Bellante, Don, and Albert N. Link. 1981. "Are Public Sector Workers More Risk Averse than Private Sector Workers?" in Industrial and Labor Relations Review, 34 (3), p. 408-412.

Geertz, Clifford. 1973. "Religion as a Culture System" in Clifford Geertz, Interpretation of Cultures, Selected Essays, New York: Basic Books, p. 90.

Gomes, F.C. 2003. Manajemen Sumber Daya Manusia, Yogyakarta: Penerbit Andi Yogyakarta, p. 180.

Greene, William H. 2002. Econometric Analysis, New Jersey: Upper Saddle River, Fifth Edition, pp. 773-774.

Hervina. 2004. "Implikasi Pembayaran Zakat Penghasilan terhadap Berkah dalam Berusaha, Studi Kasus Pengusaha Kayu di Kota Samarinda, Kalimantan Timur", Tesis, Program Pascasarjana Universitas Islam Negeri.

Http://docs.google.com/, diakses tanggal 31 Maret 2011.

Http://www.antara.co.id, diakses tanggal 12 September 2008.

Husserl, Edmund. 1966. Cartesian Meditation an Introduction to Phenomenology, The Hague: Martinus Nijhoff, p. 49.

Iqbal, Zamir and Abbas Mirakhor. 2007. An Introduction to Islamic Finance Theory and Practice, Singapore: John Wiley and Sons Pte Ltd, p. 42-43.

Kilpatrick, Franklin P., Cummings Milton C., and M. Kent Jennings. 1964. The Image of the Federal Service, Washington, DC: Brookings Institution, p. 23-24.

Pasiak, Taufik. 2007. Manajemen Kecerdasan: Memberdayakan IQ, EQ dan SQ untuk Kesuksesan Hidup, Bandung: Penerbit Mizan, p. 123-124.

Rama, Ali. 2010. "Ekonomi Syariah dan Outlook 2011" in Republika, diakses tanggal 29/12/2010. 
Rosadi, Idi. 2007. "Masyarakat dan Zakat: Respon Masyarakat terhadap Lembaga Ekonomi Islam (Studi Pengelolaan Zakat di Badan Amil Zakat Kec. Panjalu Kab. Ciamis Jawa Barat)", Tesis, Program Pascasarjana Universitas Islam Indonesia.

Shihab, M. Quraish. 2001. Tafsir Al-Mishbah, Jakarta: Lentera Hati, cet. ke-1, IV, p. 189.

Sugiyono, Statistika untuk Penelitian. 2009. Bandung: CV. Alfa Betha, p. 70-71.

Syah, Muhibbin. 1999. Psikologi Belajar, Jakarta: Logos, cet. ke-1, p. 108-113.

Syafei, Erni Suhasti. 2003. "Faktor-faktor yang Mempengaruhi Pembayaran Zakat Masyarakat Prenggan-Kotagede Yogyakarta”, Tesis, Program Pascasarjana Universitas Islam Indonesia.

Tim Redaksi. "Baznas: Potensi Zakat Nasional Rp 217 Triliun" in http://www.republika.co.id/berita/ramadhan/kabarramadhan/11/08/19/1q6ibr-baznas-potensi-zakat-nasionalrp-217-triliun, diakses tanggal 4 November 2013.

Tim Redaksi. "Potensi Zakat Indonesia Rp. 9 Triliun", in http:// www.antara.co.id, diakses tanggal 12 September 2008.

Wawancara dengan Agus, muzaki Yogyakarta, pada tanggal 21/04/2014, Rindi, muzaki yang berlatar belakang guru di Sleman pada tanggal 21/04/2014, Sukamto, muzaki Yogyakarta yang berprofesi pemilik toko kaca, pada tanggal 19/04/2014, dan Husein Fahrudi, muzaki berprofesi dosen di Yogyakarta, pada tanggal 19/04/2014. Wawancara dengan Antok di Yogyakarta, pada tanggal 22/4/2014. Wawancara dengan Irfan Helmi (24/02/2014), Yahya (25/02/2014) dan Upang Sofyan (26/02/2014).

Wawancara dengan Itoh (18/02/2014), Rafi (18/02/2014), Yanur Wibowo (18/02/2014), Tri mursito (18/02/2014), Zuhron (18/02/2014), Supomo (19/2/2014), Misbahrudin (19/2/2014), Bagas Laksono (19/2/2014), Susmono (19/2/2014), Maryo (19/2/2014), Yusuf (20/2/2014), Drajat 
(20/2/2014), Joko Adi Saputro (20/2/2014) dan Sakidi $(20 / 2 / 2014)$.

Wawancara dengan Maryo, selaku Sekretaris LAZ MUH Salatiga, pada tanggal 19/02/2014.

Wawancara dengan Misbahrudin, selaku Kepala Staf Sekretariat BAZDA Yogyakarta, pada tanggal 19/2/2014. Wawancara dengan Samino (26/02/2014), Abdul Ghafur (01/03/2014), Adang Kuswaya (19/04/2014), Ifonilla Yeniati (19/04/2014), Bashori (19/04/2014), Supartinah (22/04/2014), Idi Joko Sudono (22/04/2014), Syaerozi (22/04/2014), Rahmat Hasan (22/04/2014), Mubasirun (22/04/2014), Juz'an (22/04/2014) dan Sulistiyorini (23/04/2014).

Wawancara dengan Mukhlis selaku Ketua Prozis Ibnu Abbas Klaten, tanggal 19/02/2014.

Wawancara dengan Supomo, selaku Manajer Solopeduli Surakarta, pada tanggal 19/02/2014.

Wawancara dengan Taufikurrahman, selaku Manajer RZIS UGM $(18 / 02 / 2014)$.

Wawancara dengan Tri Mursito selaku Staf bagian Keuangan BAZ Kota Semarang (18/02/2014), Zuhron selaku Manajer LAZIS UMM (18/02/2014), Ucu Sutrisno selaku Pengelola RZI Kota Semarang (19/02/2014) dan Yusuf selaku Ketua lembaga zakat YASR Klaten (20/02/2014).

Wawancara dengan Ucu Sutrisno selaku Pengelola RZI Kota Semarang, pada tanggal 19/02/2014.

Wawancara dengan Yasmidi selaku Pengelola Lembaga Zakat Jatisari, Kecamatan Mijen, Semarang, tanggal 20/02/2014. Wawancara dengan Zuhron, selaku Manajer LAZIS UMM Magelang, pada tanggal 18/02/2014.

Wawancara dengan 13 responden lelaki, yaitu pada tanggal 9 Agustus 2012 dengan Puyawahana dan Mubasirun, dan pada tanggal 12 Agustus 2012 dengan Sigit, Giyanto, Solikhun, Zamroni, Muhsin, Abdul Aziz, Ahmadi, Nasrodin, Rohib, Farkhani dan Eko Purnomo. 
Wawancara dengan 13 para muzaki perempuan yang membayarkan zakatnya langsung ke mustahik langsung, yaitu Widayati, Win, Nafi' atul Birroh, Umi, Ismarmiyati, Lastri, Shol, Nurul, Ida, Syarifah, Aisyah, El Widuri, Peni Susapti dan ada satu responden lagi yang tidak berkenan menyebutkan nama, antara tanggal 10-12 Agustus 2012. 